\title{
ANALYSIS OF SEXUAL ASSAULT VICTIMS: BASED ON DATA FROM A ONE-STOP SERVICE CENTER IN CHUNGCHEONGNAM-DO
}

\author{
Su-Kon Kim, MD, Ye Kyu Park, MD, Yun-Dan Kang, MD \\ Department of Obstetrics and Gynecology, Dankook University College of Medicine, Cheonan, Korea
}

\section{Objective}

The aim of this study was to identify characteristics of female victims of sexual assault.

\section{Methods}

The subjects were 207 female patients who visited Chungcheongnam-do One-stop Service Center as victims of sexual assault from January 13th, 2010 to January 12th, 2012. The medical records of victims of sexual assault were analyzed retrospectively.

Results

Of 207 sexual assault victims, 48.3\% were under 19 years of age. Summer was relatively vulnerable season for sexual assaults, vulnerable time was between 14 to 18 o'clock for victims younger than 13 years and between 22 to 2 o'clock for victims older than 13 years. Most frequent place was hotel for victims older than 13 years and was victim's house victims younger than 13 years. $50.7 \%$ of assailants were strangers to the victims. The detection rate of sperm was $22.4 \%$ and the follow up rate was $30.7 \%$. $27.5 \%$ of victims were injured and $2 \%$ of victims were pregnant.

\section{Conclusion}

There were several differences between sexual assaults committed by strangers and those committed by acquaintances. Sexual assaults committed by acquaintances lasted for a longer period of time than those committed by strangers. All victims of sexual assault need some sort of urgent intervention. This study provides more accurate information about epidemiology of sexual assaults.

Keywords: Sexual assault; Victim; Epidemiology; One-stop Service Center

성폭력은 성을 매개로 피해자의 동의 없이 가해지는 정신적, 육체적 폭력으로 강간, 윤간, 강도 강간뿐 아니라 성추행, 언어적 희롱, 음란전 화, 성기노출, 어린이 성추행, 아내 강간 등 상대방 의사에 반하여 가해 진 성적행위로 모든 신체적 정신적 폭력을 포괄하는 광범위한 개념이 다. 그 중에서 강간은 피해자 동의 없이 위협 혹은 강제적인 힘으로 피 해자의 질, 구강, 항문에 남성의 성기나 신체 일부분을 삽입하는 행위 를 말하며, 성추행은 피해자의 동의 없이 성교 이외의 방법을 통한 성 적 접촉을 말한다. 성폭력은 전 세계적으로 증가추세에 있는 강력 범 죄로 $16 \%-25 \%$ 의 여성이 일생 동안 최소 한 번의 성폭력을 경험한다 는 보고가 있다[1]. 한국 형사 정책연구원의 범죄 통계정보 시스템의 통계에 따르면, 성폭력 발생건수는 지속적으로 증가하고 있다. 2001년 에 6,911건에서 2010년에는 19,939 건으로 2.9 배 증가하였으며, 발생 률도 2001년 인구 10만 명당 14.59건에서 2010년 40.8건으로 약 2.8 배 증가하였다[2]. 성폭력 피해자는 신체적 상해와 성병감염, 임신, 낙
태 이외에도 불안, 우울 등의 심리적 후유증과 사회생활 부적응 등으

Received: 2012.7.6. Revised: 2012.8.15. Accepted: 2012.9.12. Corresponding author: Yun-Dan Kang, MD

Department of Obstetrics and Gynecology, Dankook University College of Medicine, 119 Dandae-ro, Dongnan-gu, Cheonan 330-715, Korea

Tel: +82-41-550-6159 Fax: +82-41-556-3878

E-mail: yundan76@hanmail.net

This is an Open Access article distributed under the terms of the Creative Commons Attribution Non-Commercial License (http://creativecommons.org/licenses/ by-nc/3.0/) which permits unrestricted non-commercial use, distribution, and reproduction in any medium, provided the original work is properly cited.

Copyright @ 2012. Korean Society of Obstetrics and Gynecology 
로 총체적인 위기를 맞는 동시에 다양한 사회문제를 유발하게 된다. 따 라서 피해자들에 대한 사회적 지원체계가 절실히 요구된다. 또한 성폭 력 피해 당사자는 신체적 손상에 대한 적절한 의료조치와 심각한 후유 증에 대한 전문적인 치료, 가해자 처벌에 대한 법적인 증거확보가 필요 하기 때문에 신속한 의료지원이 가장 중요하다. 여성 학교폭력 원스톱 (One-stop)지원센터도 이런 제도적 장치의 일환으로 만들어졌고, 성폭 력, 가정폭력, 성매매, 학교폭력 피해자들을 지원하기 위해 의료, 상담, 수사, 법률 등의 서비스를 한 곳에서 받을 수 있도록 한 통합 지원시스 템으로서 2005년 8월 31일 서울 경찰병원내에 처음 개소한 이래 현재 전국에 21개소가 운영되고 있다. 또한 정부에서 성폭력 응급키트를 전 국 시, 도를 통해 보급하여 통일된 방법으로 필요한 증거를 수집하는 데 도움을 주고 있다. 본 연구진들은 성폭력 피해 실태 및 문제점을 파 악하기 위해 충남 원스톱지원센터 개설 후 본 센터를 방문한 피해자들 을 대상으로 성폭력 실태와 그 임상양상, 피해유형에 대하여 알아보고 자 하였다.

\section{연구대상 및 방법}

\section{1. 연구대상}

본 연구는 2010년 1월 13일부터 2012년 1월 12일까지 만 24개월 동안 성폭력으로 충남 원스톱지원센터를 방문하여 산부인과 진료를 시 행한 여성 성폭력 피해자 207 명을 대상으로 하였다.

\section{2. 연구방법}

본 연구는 충남 원스톱지원센터를 방문하여 산부인과 진료를 받은 207명 환자들의 전자의무기록을 후향적으로 고찰하여, 성폭력 피해자 의 나이, 이전 성교 유무, 성폭력 발생 추정 시간 및 피해자의 병원방 문시간, 성폭력 발생 후 병원 방문까지 소요시간, 성폭력 발생장소, 피 해자와 가해자와의 관계, 정자 검출 유무, 신체 손상 유무, 성병발생 및 임신여부, 정신과 진료의 유무를 살펴보았다. 피해자들은 여성 간호사 의 입회하에 피해상담과 신체검진을 받았고, 동시에 법적 증거자료를 수집하고 진료를 시행하였다. 진료와 증거자료는 수집 전에 피해자나
보호자의 자필서명동의를 받았다. 증거자료 수집은 표준화된 성폭력 응급 키트를 사용하여 채취하였다. 정자검출 여부는 정자채취를 위한 면봉을 이용하여 피해자의 질 속에서 swab을 하였고, 질내 분비물에서 운동성이 있는 정자를 확인하기 위해 wet smear로 직접 정자를 관찰하 였다. 산성 포스파타아제검사를 위해 wet swab을 하여 검사실로 보낼 때까지 냉장 보관하였다. 성병예방을 위해 ceftriaxone $125 \mathrm{mg}$ 을 근육 주사하였고, doxycyclin $100 \mathrm{mg}$ 을 1일 2회 7일간 경구 투여하여 복용 하도록 하였으며, metronidazole $500 \mathrm{mg}$ 을 1일 2회 경구 투여하여 7 일간 복용하게 하였다. 임신예방을 위해 강간 후 72 시간 이내 내원하 였을 경우, 응급피임약(levonorgestrel $1.5 \mathrm{mg}$ )을 1회 경구로 복용하게 하였다. 통계 분석은 SPSS ver. 18.0 (SPSS Inc., Chicago, IL, USA)를 이용하여 $\chi^{2}$ test를 통해 그룹 간 비교를 시행하였으며 통계적 유의성은 $P$ 값이 0.05 미만인 경우로 하였다.

\section{결 과}

\section{1. 성폭력 피해자의 유형과 연령분포}

성폭력 피해자들의 연령은 1세부터 61 세까지였으며, 20세 이상 성 인 피해자가 107 명 $(51.7 \%)$ 으로 가장 많았으며 13세 이하 소아피해자 는 25 명 $(12.1 \%)$ 이었다. 피해자 중 피해 당시 음주를 한 경우는 62 명 (30.0\%), 흉기로 협박을 당한 경우가 20명(9.7\%), 정신지체가 있는 경 우가 27 명(13.7\%), 약물을 복용한 경우가 1 명( $0.5 \%)$, 폭행에 의해 의식 을 잃은 경우가 2 명 $(1 \%)$ 이었다(Table 1).

\section{2. 성폭력 피해유형}

성폭력 피해 중 강간 범주에 속하는 피해가 185 건(89.4\%)이었고, 성 추행 피해는 22건(10.6\%)이었다. 강간환자 중 질성교가 165건(79.7\%), 구강성교가 4건(1.93\%), 항문성교가 0건(0\%), 질과 구강성교가 11 건 (5.3\%), 항문과 구강성교가 0 건(0\%), 질과 항문성교가 4 건 $(1.9 \%)$ 항 문과 구강성교가 0 건 $(0 \%)$, 질, 구강 항문성교가 같이 있던 건이 1 건 $(0.48 \%)$ 이었으며, 성추행은 22건(10.6\%)에서 있었다(Table 2).

Table 1. Mental status of victims

\begin{tabular}{|c|c|c|c|c|}
\hline Mental status & Under $13(n=25)$ & $13-19(n=75)$ & O\ver $19(n=107)$ & $P$-value \\
\hline Normal & $20(80.0)$ & $34(45.3)$ & $41(38.3)$ & 0.0008 \\
\hline Drunk state & $1(4.0)$ & $21(28.0)$ & $40(17.4)$ & 0.0041 \\
\hline Menace & $0(0)$ & $7(9.3)$ & $13(12.1)$ & 0.1789 \\
\hline Mental retardation & $4(16)$ & $10(13.3)$ & $13(12.1)$ & 0.8721 \\
\hline Drug & $0(0)$ & $1(1.3)$ & $0(0)$ & 0.4130 \\
\hline LOC due to violence & $0(0)$ & $2(2.6)$ & $0(0)$ & 0.1691 \\
\hline
\end{tabular}

Values are presented as number (\%).

Statistical analysis was done with chi-square test for all variables.

LOC, loss of consciousness. 
Table 2. Type of sexual assault

\begin{tabular}{|c|c|c|c|c|}
\hline Type of sexual assault & Under $13(n=25)$ & 13-19 $(n=75)$ & Over $19(n=107)$ & $P$-value \\
\hline \multicolumn{5}{|l|}{ Contact with penis } \\
\hline Vaginal & $10(40.0)$ & $69(92.0)$ & $86(80.4)$ & 0.0000 \\
\hline Oral & $1(4.0)$ & $0(0)$ & $3(2.8)$ & 0.2908 \\
\hline Anal & $0(0)$ & $0(0)$ & $0(0)$ & \\
\hline Vaginal+Oral & $1(4.0)$ & $2(2.7)$ & $8(7.5)$ & 0.3456 \\
\hline Oral+Anal & $0(0)$ & $0(0)$ & $0(0)$ & \\
\hline Vaginal+Anal & $0(0)$ & $1(1.3)$ & $3(2.8)$ & 0.5876 \\
\hline Vaginal+Oral+Anal & $0(0)$ & $1(1.3)$ & $0(0)$ & 0.4130 \\
\hline Sexual molestation & $13(52.0)$ & $2(2.7)$ & $7(6.5)$ & 0.000 \\
\hline
\end{tabular}

Values are presented as number (\%).

Statistical analysis was done with chi-square test for all variables.

Table 3. Attack time and time interval from sexual assault to the hospital

\begin{tabular}{|c|c|c|c|c|}
\hline Attack time and time interval & Under $13(n=25)$ & $13-19(n=75)$ & Over $19(n=107)$ & $P$-value \\
\hline \multicolumn{5}{|l|}{ Attack time } \\
\hline $22: 00-02: 00$ & $1(4.0)$ & $16(21.3)$ & $37(34.6)$ & 0.0037 \\
\hline 02:00-06:00 & $1(4.0)$ & $12(16.0)$ & $33(30.8)$ & 0.0039 \\
\hline $06: 00-10: 00$ & $1(4.0)$ & $4(5.3)$ & $8(7.5)$ & 0.7426 \\
\hline $10: 00-14: 00$ & $0(0)$ & $8(10.7)$ & $8(7.5)$ & 0.2219 \\
\hline $14: 00-18: 00$ & $7(28.0)$ & $8(10.7)$ & $8(7.5)$ & 0.0131 \\
\hline $18: 00-22: 00$ & $1(4.0)$ & $16(21.3)$ & $7(6.5)$ & 0.0041 \\
\hline Unknown & $14(56.0)$ & $11(14.7)$ & $6(5.6)$ & 0.0000 \\
\hline \multicolumn{5}{|l|}{ Time interval (hr) } \\
\hline Under 12 & $10(40.0)$ & $36(48.0)$ & $68(63.6)$ & 0.0314 \\
\hline $12-24$ & $1(4.0)$ & $11(14.7)$ & $21(19.6)$ & 0.1469 \\
\hline $24-48$ & $0(0)$ & $8(10.7)$ & $9(8.4)$ & 0.2415 \\
\hline $48-72$ & $0(0)$ & $3(4.0)$ & $2(1.9)$ & 0.4600 \\
\hline Over 72 & $5(20.0)$ & $9(12.0)$ & $3(2.8)$ & 0.0061 \\
\hline Unknown & $9(36.0)$ & $8(10.7)$ & $4(3.7)$ & 0.0000 \\
\hline
\end{tabular}

Values are presented as number (\%).

Statistical analysis was done with chi-square test for all variables.

\section{3. 성폭력 발생시간}

피해자가 피해시간을 정확히 기억하는 경우는 176 건(85.0\%)이었으 며, 정확히 기억하지 못하는 경우가 31 건(15.0\%)이었다. 전체적으로 피해자가 성폭력을 당했다고 진술한 시간 분포는 오후 10시부터 오전 2시까지가 54건(26.1\%), 오전 2시부터 오전 6시까지가 46건(22.2\%), 오전 6시부터 오전 10시까지가 13건(6.3\%), 오전 10시부터 오후 2시 까지가 16건(7.7\%), 오후 2시부터 오후 6시까지가 23건(11.1\%), 오후 6 시부터 오후 10시까지가 24건(11.6\%)이었다. 성폭력이 가장 많이 발 생한 시간대는 오후 10시부터 오전 2시까지였다(Table 3).

\section{4. 성폭력 발생 후 병원 방문까지 소요시간}

성폭력 피해 이후 병원을 방문할 때까지의 시간을 조사한 결과, 12시 간 이내에 방문한 경우는 114 건(55.1\%), 12시간 이후 24시간 이내였 던 경우가 33 건(15.9\%), 24 시간 이후 48시간 이내가 17 건(8.2\%), 48 시간 이후 72 시간 이내가 5건(2.4\%), 72 시간 이후였던 경우가 17 건 (8.2\%)이었으며, 병원방문까지의 시간을 정확하게 파악할 수 없는 경 우가 21건(10.1\%)이었다(Table 3). 특히 병원방문까지의 시간을 정확 하게 파악할 수 없는 21건 중, 2회 이상 지속적으로 성폭력이 이루어 진 경우가 20건이었고, 그 중 9건에서 피해자가 13세 미만의 유, 소아 였으며, 10 건에서 피해자가 정신지체를 보였다. 
Table 4. Place of sexual assault and relationship of sexual assailant to victim

\begin{tabular}{|c|c|c|c|c|}
\hline Place and relationship & Under 13 (n=25) & $13-19(n=75)$ & Over $19(n=107)$ & $P$-value \\
\hline \multicolumn{5}{|l|}{ Place } \\
\hline Victim's home & $10(40.0)$ & $12(16.0)$ & $30(28.0)$ & 0.0343 \\
\hline Assault's home & $4(16.0)$ & $13(17.3)$ & $14(13.1)$ & 0.7230 \\
\hline Company & $0(0)$ & $1(1.3)$ & $4(3.7)$ & 0.4095 \\
\hline Hotel or motel & $1(4)$ & $18(24.0)$ & $26(24.3)$ & 0.0720 \\
\hline Bar & $0(0)$ & $1(1.3)$ & $4(3.7)$ & 0.4095 \\
\hline Car & $0(0)$ & $2(2.7)$ & $6(5.6)$ & 0.3380 \\
\hline Park, outside & $4(16.0)$ & $11(14.7)$ & $7(6.5)$ & 0.1403 \\
\hline Other & $1(4.0)$ & $3(4.0)$ & $3(2.8)$ & 0.8930 \\
\hline Unknown & $5(20.0)$ & $14(18.7)$ & $13(12.1)$ & 0.3903 \\
\hline \multicolumn{5}{|l|}{ Relationship } \\
\hline \multicolumn{5}{|l|}{ Unknown person } \\
\hline Stranger & $6(24.0)$ & $20(26.7)$ & $49(45.8)$ & 0.0121 \\
\hline Internet chatting partner & $1(4.0)$ & $13(17.3)$ & $16(15.0)$ & 0.2557 \\
\hline \multicolumn{5}{|l|}{ Known person } \\
\hline Relative & $9(36.0)$ & $4(5.3)$ & $5(4.7)$ & 0.0000 \\
\hline Friend or partner & $0(0)$ & $7(9.3)$ & $2(1.9)$ & 0.0273 \\
\hline Villager & $6(24.0)$ & $26(34.7)$ & $32(29.9)$ & 0.5755 \\
\hline Unknown & $3(12.0)$ & $5(6.7)$ & $3(2.8)$ & 0.1471 \\
\hline
\end{tabular}

Values are presented as number (\%).

Statistical analysis was done with chi-square test for all variables.

Table 5. Injuries of victims, sexual transmitted disease infection and pregnancy

\begin{tabular}{|c|c|c|c|c|}
\hline Injuries, infection and pregnancy & Under $13(n=25)$ & $13-19(n=75)$ & Over $19(n=107)$ & $P$-value \\
\hline \multicolumn{5}{|l|}{ Injuries } \\
\hline Normal physical examination & $23(92.0)$ & $58(77.3)$ & $69(64.5)$ & 0.0106 \\
\hline Non-genital trauma & $1(4.0)$ & $10(13.3)$ & $31(29.0)$ & 0.0035 \\
\hline \multicolumn{5}{|l|}{ Genital trauma } \\
\hline Vaginal or perineal laceration & $0(0)$ & $4(5.3)$ & $3(2.8)$ & 0.3948 \\
\hline Contusion or abrasion & $1(4.0)$ & $1(1.3)$ & $1(0.9)$ & 0.5106 \\
\hline Non-genital trauma and genital trauma & $0(0)$ & $2(2.7)$ & $3(2.8)$ & 0.7021 \\
\hline \multicolumn{5}{|l|}{ Infection and pregnancy } \\
\hline Gonorrhea & $0(0)$ & $2(2.7)$ & $0(0)$ & 0.1691 \\
\hline Chlamydia & $1(4.0)$ & $4(5.3)$ & $11(10.3)$ & 0.3557 \\
\hline Syphilis & $0(0)$ & $0(0)$ & $1(0.9)$ & 0.6253 \\
\hline Hepatitis B & $0(0)$ & $0(0)$ & $2(1.9)$ & 0.3892 \\
\hline Human immunodeficiency virus. & $0(0)$ & $0(0)$ & $0(0)$ & \\
\hline Trichomonas & $1(4.0)$ & $4(5.3)$ & $9(8.4)$ & 0.6045 \\
\hline Other & $0(0)$ & $15(20.0)$ & $17(15.9)$ & 0.0559 \\
\hline Pregnancy & $0(0)$ & $4(5.3)$ & $2(1.9)$ & 0.2555 \\
\hline
\end{tabular}

Values are presented as number (\%).

Statistical analysis was done with chi-square test for all variables. 


\section{5. 성폭력의 지속성 및 가해자}

성폭력이 1회성으로 일어난 경우는 168건(81.2\%)이었으며, 2회 이 상 지속적으로 이루어진 경우가 39건(18.8\%)이었다. 지속적으로 성폭 력이 이루어진 39건의 피해자를 살펴보면, 피해자가 유, 소아나 정신지 체가 있는 경우가 26 건(66.7\%)이었으며, 가해자는 대부분이 가족, 친 족, 동네 주민 등 면식범에 의해 지속적으로 성폭력이 이루어진 경우로 31건(79.5\%)이었다.

\section{6. 성폭력 발생장소}

성폭력이 일어난 장소는 피해자의 집인 경우가 52 건( $25.1 \%)$, 가해자 의 집이 31건(15.0\%), 숙박업소가 45건(21.7\%)이었고 그 외 직장에서 5 건(2.4\%), 술집에서 5 건(2.4\%), 가해자의 차 안에서 8 건(3.9\%), 피해 자의 주거지역 인근 실외 및 공원 22건(10.6\%), 건물 화장실 및 옥상이 7건(3.4\%), 피해자가 어려서 기억을 못하거나 음주 등에 의해 피해장소 를 기억하지 못하는 경우가 32건(15.5\%)이었다(Table 4).

\section{7. 피해자와 가해자와의 관계}

가해자가 비면식범인 경우가 105 건(50.7\%)이었고, 면식범인 경우가 91건(44.0\%)이었으며, 피해자가 음주 등에 의해 의식상태가 혼미하여 가해자를 전혀 기억하지 못하는 경우가 11 건(5.3\%)이었다. 면식범의 경우 아는 동네 사람에 의한 경우가 64건(30.7\%)이었고, 친구이거나 연인인 경우가 9 건(4.3\%)이었다. 가족이나 친족에 의한 성폭력은 18 건(8.7\%)이었다. 비면식범의 경우는 전혀 모르는 사람인 경우가 75 건 (36.2\%)이었으며, 인터넷 채팅 등을 통해 처음 만난 사람인 경우가 30 건(14.5\%)에서 있었다(Table 4).

\section{8. 신체 손상 유무}

피해자들 중 아무런 손상을 받지 않은 경우는 150건(72.5\%)이었고, 성기 이외의 신체적 손상을 받은 경우는 42건(20.3\%)이었으며, 성기에 손상을 받은 경우는 10 건(4.8\%), 성기와 신체적 손상이 같이 있었던 경 우는 5건(2.4\%)이었다. 이 중 수술적 치료가 필요했던 경우는 한 건도 없었다(Table 5).

\section{9. 성병감염과 임신 빈도}

내원 당시 혈액학적 검사와 질에서 채취한 검체로 시행한 검사상 임 질 2건(1\%), 매독 1건(0.55\%), 클라미디아 16 건(7.7\%), 인간 면역 결핍 바이러스(human immunodeficiency virus, $\mathrm{HIV}$ ) 감염은 한 건도 없었고, 트리코모나스 감염은 14 건(6.8\%)에서 발견되었으며, 이외 ureaplasma urealyticum, mycoplasma hominis 등의 기타 감염이 42건(20.3\%)에서 발견되었다. 혈액검사상 혈청베타인간 융모성 성선자극호르몬(serum $\beta$-human chorionic gonadotropin)이 양성인 경우는 6 건이었다. 그 중 강간에 의한 임신은 4건이 있었으며, 이들에게는 치료적 유산이 시행 되었고, 나머지 2건은 사건 이전의 성관계로 인한 임신이었다. 성폭력 사건 이후 정신과 치료는 28건(13.5\%)에서 이루어졌다(Table 5).

\section{0. 정자검출 유무}

207명의 피해자 중, 본인 또는 보호자의 동의하에 정자채취를 시행 한 경우는 152 명이었으며 이 중 $22.4 \%$ 인 34명에서 정자가 검출되었 다. 소요시간에 따른 정자검출 여부를 살펴보면 사건 후 12시간 이전 에 검사를 시행한 경우는 정자가 26 명 $(76.5 \%)$ 에서 발견되었으며, 사건 후 12시간에서 24시간 이전에 검사를 시행한 경우는 6 명 $(17.6 \%)$, 사건 후 24시간에서 48시간 이전에 검사를 시행한 경우는 1명(2.9\%), 사건 후 48시간에서 72 시간 이전에 검사를 시행한 경우는 0 명 $(0 \%), 72$ 시간 이후에 검사를 시행한 경우는 1 명(2.9\%)에서 정자가 검출되었다.

\section{고 찰}

성폭력은 연령, 인종, 사회경제적 지위를 막론하고 남성과 여성 모두 에게 피해를 주는 강력범죄로 전 세계적으로 증가추세에 있으며, 국내 에서도 성과 관련된 범죄가 늘어가고 있다. 그러나 보고된 성폭력의 빈 도는 실제 일어난 사건의 일부일 것으로 추정되며, 이것은 여성의 순 결을 강조하고 있는 우리 사회에서 피해자가 죄의식을 갖게 되고, 수치 스럽게 생각하며 성폭력 피해자로 알려지는 것에 대한 두려움을 가지 기 때문일 것이다. 또한 피해여성들이 용기를 내어 고소를 한다고 해도 사법처리 과정의 이중고통을 겪어야 하는 현실이 성폭력에 대한 신고 율을 낮추게 하는 원인으로 생각된다. 그러나 과거에 비해 성폭력 피해 자들의 인식 변화로, 본인의 피해사실을 알리고 적절한 치료를 받고자 하는 노력이 많아졌기 때문에 보고율이 증가하여 발생이 증가한 것으 로 나타나게 된다. 성폭력 범죄는 피해자의 약 $15 \%$ 이하에서 범죄신고 를 하므로[3] 실제로 공식적으로 보고되는 통계보다 훨씬 많은 수의 성 폭력 범죄가 발생할 것으로 예상된다. 이와 같은 성폭력 발생의 증가는 사회적으로 성에 관한 정보를 친구나 잡지, 동영상 등을 통해 음성적으 로 얻게 되므로 성을 놀이나 쾌락의 도구로 여기는 왜곡된 성문화의 범 람, 성의 상품화, 사이버 공간을 통한 무절제한 성문화와 성매매의 확 산, 그리고 음주와 약물의 남용 등이 기여할 것으로 보인다.

성폭력 피해자는 주로 여성이며 소아나 청소년의 피해가 많은 부분 을 차지하고 있다. 우리나라의 경우 한국성폭력상담소에서 성폭력 상 담자료에 따르면 2011년 한 해 동안 총 1,151건의 성폭력 상담이 이 루어졌으며, 전체 피해자 중 13세 이하의 피해자가 $16.3 \%, 13$ 세 이상 19세의 청소년피해자가 $19.4 \%$ 에 달한다고 보고하였다[4]. 본 연구에 서는 성폭력 피해자들의 연령은 1세부터 61세까지였으며, 20세 이상 의 성인 피해자가 107 명 $(51.7 \%)$ 이었고, 13 세 이상 19 세의 청소년 피 해자가 75 명(36.2\%), 13세 미만의 유, 소아 피해자가 25명(12.1\%)이었 다. 피해자의 연령이 어리거나, 정신지체가 있는 경우에는 지속적으로 성폭력이 이루어져, 13 세 이하의 피해자 25명중 12 명(48.0\%)에서 지 속적으로 성폭력이 이루어졌으며, 정신 지체가 있는 33명의 피해자 중 16 명(48.5\%)에서 지속적으로 성폭력이 이루어졌다. 성폭력 피해 중 강 간의 범주에 속하는 피해가 185 건(89.4\%)이었고, 성추행 피해는 22건 $(10.6 \%)$ 이었으며, 특히 성추행의 경우는 13 세 이하의 아동에서 상대적 
으로 성추행의 빈도가 높았으며, 연령이 올라감에 따라 강간의 빈도가 높아졌으며, 연령에 따라 유의한 빈도의 차이가 있었다(Table 2). 성폭 력이 가장 빈발할 때는 하절기라는 보고가 있었고[5,6], 본 연구에서도 전체 207명의 피해자 중 192명의 피해자가 성폭력을 당한 계절을 기 억하였으며, 6 월에서 8월까지 하절기에 성폭력의 빈도가 가장 높아 전 체의 $30.0 \%$ 를 차지하였다. 성폭력 피해시각은 나이에 따른 차이가 있 었으며, 유·소아의 경우 14-18시 사이에 피해빈도가 가장 높았는데 하교시간, 또는 학원가는 시간 등과 관계가 있을 것으로 추론되며 이 와 관련된 다른 보고들과 일치한 결과이다[7,8]. 그 외의 연령대에서는 22-06시 사이의 밤 시간대에 가장 피해의 빈도가 높았으며, 1995년의 Im [9]의 연구나 2003년도의 Yoon 등[10]의 연구와 유사한 양상을 보 였다.

성폭력의 발생장소는 피해자의 집인 경우가 전체 207건 중 52건 (25.1\%)이었으며, 모텔, 호텔 등 숙박업소가 45 건(21.7\%)이었고 가해 자의 집이 31건(15.0\%)이었다. 피해자가 13세 미만의 소아의 경우 가 해자가 가족이나 친족과 같은 지인인 경우가 많으며, 이 경우에는 대부 분 피해자의 집 또는 가해자의 집에서 성폭력이 이루어졌다. 연령이 높 아짐에 따라 상대적으로 인터넷 채팅 등을 통해 처음 만난 사람에게서 음주 후 데이트 강간이 많이 일어나며 그에 따라 성폭력의 장소가 모텔 이나 호텔 등의 숙박업소에서 많이 이루어졌다.

2011년 한국성폭력상담소의 자료에 따르면 성폭력은 '아는 사람에 의한 피해가 $85.1 \%$ 를 차지한다고 하였으며, 이를 연령별로 살펴보면, 성인은 직장 관계에 있는 사람에 의한 피해가 $32.4 \%$ 로 가장 많았으며, 청소년은 학교와 관계가 있는 사람에 의한 피해가 $28.3 \%$, 유아, 소아의 경우 친족, 친인척 등에 의한 피해가 $50.5 \%$ 를 차지한다고 하여 성폭력 이 피해자의 생활공간이나 일상생활에서 빈번하게 일어난다고 보고 하 였다[4]. 본 연구에서는 가해자가 비면식범인 경우가 105 건(50.7\%)이 었다, 면식범인 경우가 91 건(44.0\%)이었으며, 피해자가 음주 등에 의 해 의식상태가 혼미하여 가해자를 전혀 기억하지 못하는 경우가 11건 (5.3\%)였다. 특히 13 세 이하의 경우 가족이나 친족에 의한 성폭력은 전 체 25건 중 친족에 의해 성폭력이 이루어진 경우가 10 건(40\%)을 차지 하여 한국성폭력상담소의 자료와 비슷한 결과를 보였으며, 가족이나 친족에 의한 성폭력의 빈도는 연령에 따라 유의한 빈도의 차이가 있었 다. 또한 동네 주민에 의한 경우가 6건(24.0\%), 비면식범에 의해 성폭 력이 이루어진 경우는 7건(28\%)으로 대부분의 사건이 면식범에 의해 일어났다. 또한 30세 이후의 연령대에서는 전혀 모르는 타인에 의해 성 폭력을 당하는 경우가 49 건(45.8\%)으로 상대적으로 타 연령군에 비해 발생 빈도가 높았으며, 연령군간 유의한 빈도의 차이가 있었다.

2008년 Song 등[11]은 면식범에 의해 성폭력이 일어난 경우 성폭력 횟수가 2회 이상 지속적으로 이루어졌으며, 성폭력 후 의료기관에 내 원할 때까지 기간도 길다고 하였다. 본 연구에서도 성폭력 피해 횟수가 2 회 이상인 경우는 40건이었고, 비면식범에 의한 사건의 경우에는 2회 이상의 반복적인 성폭력이 8 명(20.0\%)에 해당하였으나, 면식범에 의한 사건인 경우는 2회 이상의 반복적인 경우가 32 명(80.0\%)에서 있었다. 또한 마지막 성폭력 후 원스톱지원센터에 내원하여 검사까지의 기간도
가해자가 비면식범인 경우에는 105 건 중 86 건(81.9\%)에서 24시간 이 내에 검사가 이루어졌으나, 면식범에 의한 피해인 경우는 24시간 이내 에 검사가 이루어진 경우는 91 건 중 54건(59.3\%)에 불과하여 면식범 에 의한 성폭력의 경우 반복적으로 성폭력이 이루어졌으며, 내원까지 의 기간도 오래 걸린 점을 알 수 있었다.

성폭력 피해자는 신체적 상해와 성병감염, 임신, 낙태 이외에도 불안, 우울 등의 심리적 후유증과 사회생활의 부적응 등으로 총체적인 위기 를 맞게 되며 다양한 사회문제를 유발하게 된다. 따라서 피해자들에 대 한 사회적 지원체계가 절실히 요구된다. 성폭력 피해 후 가능한 빠른 시간 내에 검진이 필요한 이유는 신체적 상해에 대한 치료, 임신의 예 방, 성매개 감염 방지와 정신 심리적 지지요법 이외에도 법적인 증거물 의 확보가 신속히 이루어져야 하기 때문이다. 성폭력의 증거인 정액의 증명은 정자를 확인하는 것이 절대적이지는 않으나, 성교가 행해졌다 는 증거가 되어 매우 중요하다[12]. 일반적으로 성관계 후 운동성이 있 는 정자는 질에서 8시간까지 관찰되며 자궁경부점액에서는 2-3일까지 관찰된다. 운동성이 없는 정자의 경우 질이나 직장에서 사정 후 24시 간까지 관찰되며 자궁경부점액에서는 17 일까지도 관찰될 수 있다. 따 라서 범행사건 이전의 성관계 일시를 반드시 기록하는 것이 중요하며, 응급검사에서 정자가 관찰되더라도 강간의 직접적인 증거로 속단하는 것은 위험하다. 2011년 Kim 등[13]은 피해자에게서 정액이 발견되었을 경우 피해시간부터 검사까지의 시간이 짧을수록 발견할 가능성이 높다 고 하였으며, 정액이 발견된 경우의 $70.4 \%$ 에서 12 시간 내에 검사가 이 루어졌다고 보고하였다. 본 연구의 경우 152 명의 피해자에서 vaginal wet mounts를 현미경으로 검사하여 정자 유무를 조사한 결과 $22.4 \%$ 인 34 건에서 정자가 검출되었고, 소요시간에 따른 정자검출 여부를 살펴 보면 사건 후 12시간 이전에 검사를 시행한 경우 정자가 26건(76.5\%) 에서 발견되어 2011년 Kim 등[13]의 연구와 비슷한 결과를 볼 수 있었 다. 일반적으로 성폭력 피해환자의 $50 \%$ 미만에서 정액을 발견할 수 있 으며 경과된 시간, 무정자증, 정관수술의 과거력, 피임기구 등의 사용, 피해 후 질세척 등 여러 가지 변수가 작용할 수 있다. 그러므로 정자가 확인되지 않더라도 사람의 정액에서 활성도가 높은 산성 포스파타제 (acid phosphatase)를 측정해 볼 수 있는데 무정자증에서도 활성이 떨 어지지 않으며 보통 2-3일 정도 양성으로 나타난다. 따라서 산성 포스 파타제에 대한 검사는 반드시 시행되어야 한다. 질내 고유의 정상적인 산성 포스파타제 활성도는 $200 \mathrm{UU} / \mathrm{L}$ 미만이나, 질내 산성 포스파타제 의 활성도가 $300 \mathrm{IU} / \mathrm{L}$ 이상일 때에는 정액이 있다는 것을 강력히 암시 하며, 이것은 지난 72시간 이내에 사정된 것임을 나타낸다. 또한 최근 에는 혈액, 정액, 피부, 체모로부터 DNA를 채취하여 가해자를 확인하 는 방법이 이용되고 있다.

성폭력 당시 성기 손상과 신체 손상의 빈도는 보고하는 연구자마다 편차가 매우 큰데, Sugar 등[14]은 성폭력 피해자 중 52\%에서 신체 손 상이 있었으며, $20 \%$ 의 피해자에서 성기-항문 손상이 있었고, 피해자 중 $41 \%$ 에서는 손상이 발견되지 않았다고 보고하였으며, Riggs 등[15] 은 성폭력 피해자 중 $67 \%$ 에서 신체 손상이 있었으며, $53 \%$ 의 피해자에 서 성기-항문 손상이 있었고, 피해자 중 $20 \%$ 에서는 손상이 발견되지 
않았다고 보고하였다. 이는 피해자의 인구학적 특성, 가해자의 인구학 적 특성, 폭행 후 의료기간에 내원하기까지의 시간, 검사자의 경험 및 검사방법 등에 의해 영향을 받는다. 본 연구에서는 성기에 손상을 받 은 경우는 10 건(4.8\%)에서 발생하였으며, 성기 이외의 신체적 손상을 받은 경우는 42 건(20.3\%)에서 발생하였다. 성기와 신체적 손상이 같이 있었던 경우는 5건(2.4\%)이었으며, 피해자 중 150건(72.5\%)에서는 손 상이 발견되지 않았다. Jones 등[16]은 청소년 피해자에서 성기 손상이 성인에 비해 더 많다고 보고하였으며, 본 연구에서도 청소년기 여성에 서 성기 손상이 있는 비율이 $9.3 \%$ 로 성인여성 피해자에서 $6.5 \%$ 에 비 해 흔하게 나타났다. 또한 성폭력 당시 성기 이외의 신체적 손상은 피 해자의 나이가 많아질수록 더 흔하며 이것은 피해자가 반항하면서 손 상을 입게 되는 것으로 보인다[14]. 본 연구의 결과도 19세 이상의 여 성에서 신체 손상이 있는 비율이 $29.0 \%$ 로 유아에서 $4.0 \%$, 청소년 피 해자에서 $13.3 \%$ 에 비해 통계적으로 유의하게 높은 것으로 나타났다.

성폭력 피해자들은 반드시 내원 당시 필요한 임상병리검사를 하여야 하며, 임신검사(1-3주), 매독 혈청검사(4-6주), B형 간염 예방접종(0, 1,6 개월), HIV screen (0,1, 6, 12개월) 주기적으로 추적 관찰해야 한 다[17]. 본 연구에서 사건 이전에 성경험이 없는 피해자는 55명이었으 며, 성경험이 있는 피해자는 152명이었다. 이전에 성경험이 없는 사람 에게서 새로운 성매개성 질환이 나타난 경우는 55명 중 11명(20.0\%) 이었으며, 이전에 성경험이 있는 사람에게서 성매개성 질환이 나타난 경우는 152 명 중 56 명(36.8\%)에서 발생하였다. 따라서 이러한 차이는 성매개성 질환이 성폭력에 의해 새로 발생되었을 가능성도 있지만, 이 전에 성경험이 있는 사람에게서는 이전에 성매개성 질환을 가지고 있 는 사람이 성폭력 이후 검사를 받게 되고 질환이 발견이 되었을 가능성 이 더 높다고 생각된다.

피임을 제대로 하지 못한 상태에서 성폭력 후의 임신율은 2\%-5\% 정도로 알려져 있다[3]. 본 연구에서는 임신검사상 음성인 모든 피해자 에게 최종 월경일과 관계없이 예방적으로 사후 피임약을 처방하였으 며, 이들 중 추적 진료가 된 환자에서 임신된 피해자는 발생되지 않았 다. 그러나 강간에 의한 임신은 4건(1.9\%)에서 있었는데, 이 피해자들 은 지속적인 강간을 당해온 피해자들이었으며, 피해 당시 임신 방지를 위한 사후 피임약이 투여되지 않은 환자들이었다.

성폭력 피해자들에게는 성병 및 임신의 발생이 의학적으로 중요한 문제로 추적 관찰이 필요하나 실제 추적 진료율은 Holmes 등[18]에 따르면 31\% 정도라고 한다. 그 동안의 국내 보고를 살펴보면 2008년 $\mathrm{Kim}$ 등[19]은 피해자의 재진율이 $11.6 \%$ 라고 보고하고 있고, 2011년 $\mathrm{Kim}$ 등[13]은 피해자의 $11.3 \%$ 에서 추적관찰이 시행되었다고 보고하였 다. 본 연구에서도 내원 시 성폭력 피해자에게 필요한 임상병리검사 및 성병을 예방하기 위해 항생제를 투여 하였으며, 성폭력을 당한 후 72 시간 내에 병원에 내원했을 경우 임신검사상 음성인 모든 피해자에게 최종월경일과 관계없이 사후 피임약을 처방한 후 추적관찰의 필요성을 교육하였으나 산부인과 추적 진료가 전체 207명의 환자 중 64명에서 이루어졌고, 추적 관찰률은 $30.7 \%$ 이었다.

성폭력은 피해자에게는 심각한 위기상태이므로 정신과 상담은 내원
즉시 빨리 시작하는 것이 좋다[17]. 그러므로 처음 내원 당시 문진을 시행할 때, 정서적 충격에서 벗어날 수 있도록 편안한 분위기를 만들어 주어야 하며, 이러한 환경이 조성될 때 좀 더 정확하고 많은 정보를 환 자에게 알아낼 수 있다. 성폭력 피해자들의 정신적인 피해 회복은 보 통 수년씩 걸리며, 피해자들은 손상 후 스트레스 장애가 일어날 수 있 음을 주지해야 한다. 피해 후 수시간 내지 수일간은 섭식장애, 불면, 불안을 겪으며 수개월 내지 수년에 걸쳐 사회적 관계와 생활을 다시 정리하게 된다. 장기적으로 왜곡된 성의식을 가질 수 있어 이성간의 문제나 결혼생활에 장애를 받을 수 있으며, 성격장애 등 각종 정신과 적 문제로 괴로움을 겪을 수 있다[20]. 내원 1-2주 후에 정신과적 추 적관찰을 해야 하며, 숙련된 정신과의사에게 환자를 의뢰하는 것이 필 요하다[17]. 본 연구에서는 피해자 중 13세 이하의 유·소아에서 9건 (40.0\%), 청소년의 경우는 10건(13.3\%), 성인의 경우는 9건(8.4\%)에 서 정신과 진료가 이루어졌으며, 전체적으로는 28건(13.5\%)에서 정신 과 진료가 이루어졌다.

성폭력은 전 세계적으로 증가추세에 있으며 피해자에게 신체적 상해 및 성병감염, 임신 이외에 심리적 후유증과 사회생활의 부적응 등 총체 적인 위기를 맞게 하는 심각한 강력 범죄이다. 그러므로 성폭력을 줄이 기 위해서는 무엇보다 예방이 중요하다는 것을 인지하여야 한다. 또한 수치심과 죄의식을 갖게 되고 성폭력 피해자로 알려지는 것을 두려워 하게 되는 사회적 풍토와 사법처리 과정에서 이중고통을 겪어야 하는 현실 때문에, 성폭력 환자들이 신고나 상담, 지속적인 추적관찰을 하지 않게 된다. 따라서 피해자들의 상담률을 높일 수 있도록 개인적인 비밀 이 보장되는 신고체계의 개발과 홍보가 중요하며, 주로 성폭력의 가해 자 및 피해자가 청소년임을 감안할 때 성폭력에 대한 성교육을 보다 구 체적으로 시행해야 할 것이다. 또한 피해자들에게도 신체적, 정신적 후 유증을 예방하기 위한 추적 관찰이 중요함을 효과적으로 교육하여 지 속적인 추적관찰을 할 수 있도록 도와주어야 할 것이고, 각 방면의 전 문가들로 구성된 팀에 의한 조직적인 치료가 필요하며 법과 제도적으 로 피해자들을 위한 지원체계가 보강되어야 할 것이다.

본 연구의 제한점으로는 일정지역내의 거주자만을 대상으로 하였기 때문에 연구결과를 일반화하기에는 한계가 있다는 점을 들 수 있으며, 또한 성폭력 범죄는 피해자의 약 $15 \%$ 이하에서 범죄신고가 이루어지 므로 본 연구결과가 전체 성폭력 피해자의 특성을 반영하지 못할 수도 있다. 그러나 원스톱지원센터의 개원으로 성폭력 피해자들에 대한 접 근, 지원 및 표준화 된 치료를 하게 되었으며, 앞으로 성폭력 피해에 연 구를 위한 토대가 마련되었다고 사료된다. 또한 정부에서 성폭력 응급 키트를 전국 시, 도를 통해 보급하여 표준화된 증거수집이 이루어질 수 있도록 도움을 주고 있으므로 앞으로 전국단위의 연구가 실행될 수 있 을 것으로 예상된다.

\section{References}

1. Bowyer $L$, Dalton ME. Female victims of rape and their genital 


\section{KOREAN JOURNAL OF OBSTETRICS \& GYNECOLOGY}

Su-Kon Kim, et al. Sexual assault, One-stop Service Center

injuries. Br J Obstet Gynaecol 1997;104:617-20.

2. Korean Inistitute of Criminology. Reported crime s邓tatistics [Internet]. Seoul (KR): Korean Inistitute of Criminology; c2012 [cited 2012 Mar 20]. Available from: http://crimestats.or.kr/ hpweb/main/index.k2?cmd=sub_2.

3. Holmes MM, Resnick HS, Kilpatrick DG, Best CL. Raperelated pregnancy: estimates and descriptive characteristics from a national sample of women. Am J Obstet Gynecol 1996;175:320-4.

4. Korea Sexual Violence Relief Center. 2011 Korea Sexual Violence Relief Center counseling statistics and counseling trend analysis [Internet]. Seoul (KR): Korea Sexual Violence Relief Center; c2012 [cited 2012 Mar 5]. Available from: http:// www.sisters.or.kr/index.php/subpage/pds/1.

5. Anderson CA. Temperature and aggression: effects on quarterly, yearly, and city rates of violent and nonviolent crime. J Pers Soc Psychol 1987;52:1161-73.

6. Smolensky MH, Reinberg A, Bicakova-Rocher A, Sanford J. Chronoepidemiological search for circannual changes in the sexual activity of human males. Chronobiologia 1981;8:21730.

7. Kim GJ. Adolescent sexual assault: experiences at sexual assault clinic. Korean J Obstet Gynecol 2005;48:1645-53.

8. Jo KH, Yoon YJ, Lee SA, Kim JW, Won HS. A gynecologic aspects of child sexual abuse. Korean J Obstet Gynecol 2004;47:132-8.

9. Im MH. Rape in the district of Young Nahm: a review of 36 cases. Korean J Obstet Gynecol 1995;38:1211-8.

10. Yoon WS, Kweon I, Lee GS, Hur SY, Kim SJ, Choi BM. Clinical analysis of female sexual assault victims. Korean J Obstet Gynecol 2003;46:283-7.
11. Song SH, Kim SY, Chung YK, Shin YM. A study of sexual assault on children and adolescents: based on data from a onestop service center. J Korean Acad Child Adolesc Psychiatry 2008;19:162-7.

12. Sharpe $N$. The significance of spermatozoa in victims of sexual offences. Can Med Assoc J 1963;89:513-4.

13. Kim SK, Lee MY, Choi SJ, Ahn TG, Seo JA, Jeong HY. Analysis of sexual assault victims. Korean J Obstet Gynecol 2011;54:3742.

14. Sugar NF, Fine DN, Eckert LO. Physical injury after sexual assault: findings of a large case series. Am J Obstet Gynecol 2004;190:71-6.

15. Riggs N, Houry D, Long G, Markovchick V, Feldhaus KM. Analysis of 1,076 cases of sexual assault. Ann Emerg Med 2000;35:358-62.

16. Jones JS, Rossman L, Wynn BN, Dunnuck C, Schwartz N. Comparative analysis of adult versus adolescent sexual assault: epidemiology and patterns of anogenital injury. Acad Emerg Med 2003;10:872-7.

17. Lee IS. The guideline of management of sexual assault victim. Korean J Obstet Gynecol 2005;48:821-43.

18. Holmes MM, Resnick HS, Frampton D. Follow-up of sexual assault victims. Am J Obstet Gynecol 1998;179:336-42.

19. Kim JS, Park JY, Yoon YJ, Kim JH, Lee SA. Clinical significance of genital injury, detection of sperm, acid phosphatase activity, prostate specific acid phosphatase activity as proof of rape. Korean J Obstet Gynecol 2008;51:882-91.

20. Schwartz IL. Sexual violence against women: prevalence, consequences, societal factors, and prevention. Am J Prev Med 1991;7:363-73. 


\section{성폭력 피해자에 대한 분석: 충남 원스톱지원센터 내원자를 중심으로}

\section{단국대학교 산부인과학교실}

김수곤, 박예규, 강윤단

\section{목적}

성폭행으로 충남 원스톱지원센터를 내원한 피해자의 연령분포, 피해자의 특성, 범행시간, 범행장소, 가해자의 특성, 생식기와 비생기에 생 긴 외상의 빈도, 성병 및 임신의 빈도를 알아보고자 하였다.

\section{연구방법}

2010년 1월 13일부터 2012년 1월 12일까지 만 24개월 동안 성폭행을 당하여 충남 원스톱지원센터를 내원한 여성 207명을 대상으로 후 향적으로 조사하였다.

\section{결과}

207 명의 성폭력 피해자 중에서 48.3\%는 19세 이하였다. 여름이 비교적 성폭력이 빈발하는 계절이었으며, 13 세 이하의 연령군에서는 성 폭력이 14-18시 사이에 가장 많이 일어났으며, 14세 이상의 연령에서는 성폭력이 22-02시 사이에 가장 많이 일어났다. 성폭력 범행 장 소는 13세 이하의 연령군에서는 피해자의 집에서 가장 많이 일어났고, 14 세 이상의 연령군에서는 숙박업소에서 성폭력이 가장 많이 일어 났다. 50.7\%에서는 비면식범에 의해 피해가 일어났다. 정자의 발견율은 $22.4 \%$ 이었으며, 피해자의 추적 관찰률은 $30.7 \%$ 이썼다. $27.5 \%$ 의 피해자가 외상을 입었으며, $2 \%$ 의 피해자가 임신이 되었다.

\section{결론}

비면식범에 의해 성폭력이 일어난 경우와 면식범에 의해 일어난 성폭력의 경우 몇 가지 차이가 존재하는데, 면식범에 의한 성폭력이 이루 어진 경우에는 장기간 동안 지속적으로 이루어졌다. 모든 성폭력 피해자는 응급에 준하는 치료가 필요하다. 본 연구는 성폭력 피해자들의 역학조사를 통해 성폭력이 실태와 문제점을 파악하는 데 정확한 자료를 제공할 것이다.

중심단어: 성폭력, 피해자, 역학, 원스톱지원센터 